\title{
Efektivitas Metode Survey, Question, Read, Recite, Reflect, Review dalam Meningkatkan Keterampilan Membaca Pemahaman untuk Anak Berkesulitan Belajar
}

\author{
Safaruddin $^{1}$, Nurhastuti $^{2}$, Fatmawati $^{3}$, Elisa Cristina Silitonga ${ }^{4}$ \\ ${ }^{1234}$ Universitas Negeri Padang,Indonesia \\ Email: Safaruddin0366@fip.unp.ac.id
}

\section{INFORMASI ARTIKEL}

Terkirim 03 Agustus 2018

Revisi 21 Agustus 2018

Diterima 25 September 2018

Kata kunci:

SQ4R, Membaca Pemahaman, Anak

Berkesulitan Belajar

\begin{abstract}
ABSTRAK
Artikel ini bertujuan untuk membahas efektivitas keterampilan membaca pemahaman untuk anak berkesulitan belajar. Melalui metode survey, question, read, recite, reflect, review (SQ4R) anak dilatih pemahaman membaca dengan langkah-langkah untuk mendapatkan informasi yang menyeluruh. Jenis penelitian yang peneliti gunakan adalah metode eksperimen dengan desain pra-eksperimen dengan satu kelompok desain pretest-posttest. Implementasi dalam penelitian ini menggunakan uji Mann Whitney. Berdasarkan hasil yang didapat menyatakan bahwa SQ4R secara signifikan dapat meningkatkan keterampilan membaca pemahaman untuk anak berkesulitan belajar.
\end{abstract}

This is an open access article distributed under the Creative Commons 4.0 Attribution License, This license lets others remix, tweak, and build upon your work even for commercial purposes, as long as they credit you and license their new creations under the identical terms $\odot 2018$ by author and Universitas Negeri Padang.

\section{Pendahuluan}

Minat baca di Indonesia menduduki peringkat 60 dari 61 negara (Miller, 2016). Permasalahan membaca yang dihadapi oleh Indonesia juga dihadapi oleh negara lain. Seperti di Amerika, hanya sekitar 34\% siswa kelas empat dan delapan yang memiliki kemampuan pemahaman membaca yang lebih tingg(Joseph, Alber-Morgan, Cullen, \& Rouse, 2016). Rendahnya pemahaman membaca menjadi masalah yang sangat serius pada saat ini. Pada anak berkebutuhan khusus memiliki permasalahan yang lebih serius jika dibandingkan dengan anak pada umumnya sehingga membutuhkan penanganan khusus. Keterampilan membaca merupakan salah satu unsur dari keterampilan berbahasa yang memiliki posisi yang sangat penting dalam proses pembelajaran di sekolah dasar (Wahyuni, 2016). Kegiatan membaca memiliki tahapan yang terdiri atas dua bagian yaitu keterampilan membaca permulaan atau membaca mekanik dan keterampilan membaca pemahaman atau membaca lanjut. Keterampilan membaca lanjutan adalah membaca pemahaman. Membaca pemahaman dapat dikembangkan dengan perolehan keterampilan bahasa dasar yang lengkap dan benar (Akkaya, 2011: 69; Balta \& Demirel, 2012; Başar \& Gürbüz, 2017).

Membaca pemahaman adalah suatu proses untuk mengenali atau mengidentifikasi teks, kemudian mengingat kembali isi teks. Membaca pemahaman juga dapat berarti sebagai suatu kegiatan membuat urutan tentang uraian/menggorganisasi isi teks, bisa mengevaluasi sekaligus dapat merespon apa yang tersurat atau tersirat dalam teks (Khusniyah \& Lustyantie, 2017; Dalman, 2013). Artikel ini dilatarbelakangi oleh permasalahan yang barada di SD N 14 Koto Panjang Padang, terdapat lima orang anak kesulitan belajar kelas III, saat melakukan pengamatan pada siswa, peneliti mengamati proses pembelajaran tentang kegiatan membaca, terlihat siswa bosan dan tidak serius dalam belajar dikarenakan anak malas dan sulit mengerti tentang apa yang dibacanya. Setelah itu, saya mewawancarai Guru Pendidik Khusus (GPK) (Sudarto, 2017; Taufan \& Mazhud, n.d.) yang ada disekolah tersebut, ternyata dikelas tersebut memang ada anak kesulitan belajar dilihat juga dari nilai rapor anak dibawah rata-rata. Ketika proses belajar mengajar dikelas guru dalam mengajar sudah menggunakan berbagai metode keterampilan seperti ceramah, demonstasi dan penugasan namun masih kurang menarik perhatian siswa. Menurut penuturan guru, membaca sudah sering diajarkan kepada anak namun anak masih belum berhasil mencapai nilai yang diinginkan oleh guru terbukti dari nilai rapor dan nilai ulangan harian anak masih dibawah rata-rata. Sehubungan dengan keterampilan membaca dalam memahami dan menjelaskan bacaan secara lisan dan tulisan, mengungkapkan pikiran, perasaan, pengalaman, dan petunjuk dengan cara membaca dan memberikan tanggapan/saran, serta memahami teks dengan membaca nyaring, membaca intensif dan membaca dongeng.

membaca pemahaman merupakan keterampilan membaca yang berada pada urutan yang lebih tinggi (Dalman, 2013). Membaca pemahaman adalah membaca secara kognitif (membaca untuk memahami). Membaca pemahaman sangat menantang bagi peserta didik dengan disleksia dan kesulitan membaca, karena banyak guru menekankan bahwa memahami teks-teks tertulis menjadi tujuan utama dari membaca (Edmonds, Vaughn, Wexler, Reutebuch, kabel, Tackett dan Schnakenberg, 2009; Awada \& Gutiérrez-Colón Plana, 2018).. berdasarkan pengertian tersebut dapat dimaknai bahwa keterampilan membaca pemahaman adalah kegiatan membaca dengan memahami apa isi bacaan dengan baik dan benar sesuai dengan isi teks bacaan. Berdasarkan permasalahan yang ditemukan maka harus ada upaya yang dilakukan untuk menyelesaikan permasalahan membaca yang sedang dihadapi oleh para siswa. Salah satu faktor penentu yang menjadi pendukung keberhasilan dalam membaca pemahaman adalah metode yang digunakan oleh guru. Metode SQ4R adalah metode yang diterapkan dalam keterampilan membaca pemahaman yang diawali pelaksanaan langkah-langkah yang menekankan pada keterampilan pada keterampilan membaca pemahaman. 
Metode SQ4R merupakan suatu metode pembelajaran yang dapat diaplikasikan pada setiap anak, metode ini menekankan pada keterampilan anak dalam membaca pemahaman. Metode SQ4R merupakan pengembangan dari metode SQ3R dengan menambahkan unsur reflect, yaitu aktivitas memberikan contoh dari bahan bacaan yang relevan (Shoimin, 2014). Selain itu, menurut Ermanto (2008:89) metode SQ4R adalah suatu keterampilan dengan langkah membaca yang digunakan untuk memperoleh informasi secara menyeluruh dari suatu bacaan. Dari pengertian tersebut dapat dimaknai bahwa metode SQ4R adalah suatu metode yang digunakan untuk mengembangkan keterampilan membaca dengan langkah-langkah yang diberikan sehingga anak dapat lebih mudah memahami isi bacaan dari apa yang dibaca. Enam langkah yang digunakan adalah survey, question, read, recite, reflect, review. Metode ini merupakan pengembangan dari metode SQ3R dengan menambahkan unsur Reflect, yaitu aktivitas guru memberikan suatu permasalahan yang berhubungan dengan konteks aktual yang relevan dengan kehidupan sehari-hari. Kemudian siswa akan mencari solusi dari permasalahan tersebut berdasarkan pengetahuan yang telah mereka peroleh dari tahap read (Iswahyudi, 2016: 35). Kelebihan dan kelemahan strategi SQ4R adalah sebagai berikut :Kelebihannya yaitu 1) dengan adanya tahap survei pada awal pembelajaran, hal ini membangkitkan rasa ingin tahu siswa tentang materi yang akan dipelajari, sehingga dapat meningkatkan motivasi siswa dalam belajar. 2) Siswa diberi kesempatan mengajukan pertanyaan dan mencoba menemukan jawaban dari pertanyaanya sendiri dengan melakukan kegiatan membaca. Dengan demikian, dapat mendorong siswa berpikir kritis, aktif dalam belajar, dan pembelajaran bermakna. 3) materi yang dipelajari siswa melekat untuk periode waktu yang lebih lama. Kelemahannya yaitu 1) strategi ini tidak dapat diterapkan pada semua pokok mata pelajaran. 2) guru akan mengalami kesulitan dalam mempersiapkan buku bacaan untuk masingmasing siswa jika tidak semua siswa memiliki buku bacaan (Shoimin, $2014: 194-195$ ).

Anak kesulitan belajar adalah salah satu bagian dari anak yang berkebutuhan khusus. Menurut Jamaris (2009) anak kesulitan belajar "adalah suatu kondisi yang menunjuk pada sejumlah kelainan yang berpengaruh pada pemerolehan, pengorganisasian, penyimpanan, pemahaman, dan pengguaan informasi secara verbaldan non verbal. Akibat dari keadaan ini maka individu yang mengalami kesulitan belajar mengalami kesulitan dalam mengoperasikan pikiran karena kondisi yang berkaitan dengan kesulitan belajar yang mempengaruhi fungsi intelektual secara umum". Anak kesulitan belajar membaca adalah anak yang mengalami kekeliruan dalam mengenal kata, kekeliruan memahami bacaan tampak pada banyaknya kekeliruan dalam memjawab pertanyaan yang terkait dengan bacaan, tidak mampu mengemukakan urutan cerita yang dibaca dan tidak mampu memahami tema dari suatu cerita (Abdurrahman 2012). Adapun maksud dari diadakannya penelitian ini bertujuan untuk membuktikan bahwa metode SQ4R efektif dalam meningkatkan kemampuan membaca pemahaman bagi Anak Berkesulitan Belajar kelas III SD N. 14 Koto Panjang Padang. Hasil dari penelitian yang dilakukan ini memiliki harapan agar bermanfaat dan mampu membantu berbagai pihak yang berkaitan dengan pendidikan bagi anak kesulitan belajar membaca di Sekolah reguler atau Sekolah Penyelenggara Inklusif.Memuat tentang ruang lingkup, latar belakang tujuan, dan manfaat penelitian. Bagian ini hendaknya memberikan latar belakang agar pembaca dapat memahami dan menilai hasil penelitian tanpa membaca laporan-laporan sebelumnya yang berkaitan dengan topik. Manfaatkanlah pustaka yang dapat mendukung pembahasan.

\section{Metode}

Metode yang digunakan dalam penelitian ini adalah metode eksperimen, menggunakan pre-experimental design atau sering juga disebut dengan quasi experiment dengan jenis one group pretest-postest design. Quasi eksperimen (eksperimen semu) yaitu suatu prosedur penelitian yang diajukan untuk mengetahui pengaruh dari kondisi yang sengaja diadakan terhadap suatu situasi, kegiatan atau tingkah laku individu atau kelompok individu (Safaruddin, Efrina, \& Yunus, 2013). Observasi dilakukan sebanyak dua kali yaitu sebelum eksperimen dan setelah eksperimen. pelaksanaan yang dilakukan sebelum eksperimen (O1) disebut pretest, dan pelaksanaan sesudah eksperimen (O2) disebut posttest. Desain penelitian yang digunakan dalam penelitian ini adalah one group pretest-posttest design, artinya penelitian dilaksanakan pada suatu kelompok tanpa adanya kelompok pembanding. desain ini melakukan observasi sebanyak dua kali (Suharsimi, 2006). Sebelum diberikan perlakuan, kelompok diberikan pretest setelah itu diberikan perlakuan dan barulah diberikan posttest. Sehingga akan terlihat perbandingannya sebelum diberikan perlakuan dengan setelah diberikan perlakuan.

Variabel dalam penelitian ini terdiri dari dua variabel yaitu variabel bebas dan variabel terikat. Variabel terikat dalam penelitian ini adalah kemampuan membaca pemahaman. Sedangkan variabel bebas dalam penelitian ini adalah metode SQ4R. Subjeknya adalah 5 orang anak kesulitan belajar kelas III di SD N 14 Koto Panjang, Padang. Teknik pengumpulan data yang digunakan dalam penelitian ini adalah dengan pemberian tes dan mencatat hasil kegiatan yang dilakukan dan menghitung keberhasilan anak dengan benar dari kriteria yang telah ditentukan. Tes yang diberikan didalam penelitian ini adalah berupa instrumen tes. Anak diberikan perintah untuk membaca dan menjawab pertanyaan sesuai dengan langkah metode metode Survey, Question, Read, Recite, Reflect, Review (SQ4R). Jika anak menjawab dengan benar nilainya 1, jika anak menjawab salah diberi nilai 0, sehingga nilai maksimal yang dapat diperoleh anak dalam keterampilan membaca pemahaman adalah 10.

diuraikan secara terperinci dan jelas mengenai bahan yang digunakan dan cara kerja yang dilaksanakan, termasuk metode statistika. Cara kerja yang disampaikan hendaknya memuat informasi yang memadai sehingga memungkinkan penelitian tersebut dapat diulang dengan berhasil.

\section{Hasil Penelitian dan Pembahasan}

Agar proses pengolahan data lebih mudah, sebelumnya harus memasukkan nilai pre-test dan post-test kedalam sebuah tabel untuk melihat kemampuan awal dan kemampuan akhir subjek yang diteliti.

Tabel 1. Nilai Pre-test Dan Post-test

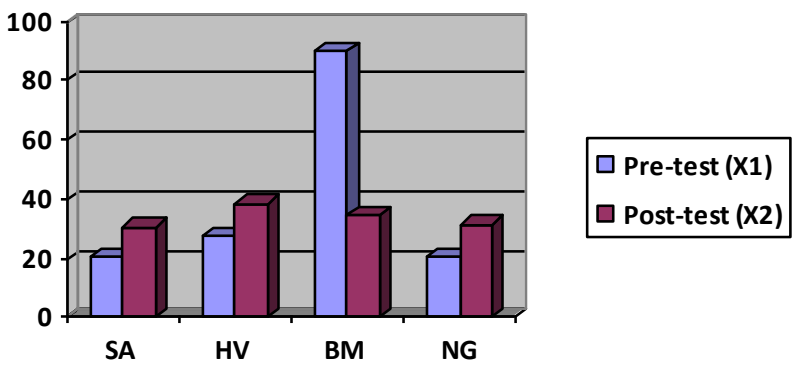

Dari grafik tersebut, dapat didefenisikan persentase pre-test atau kemampuan awal dan kemampuan setelah diberikan perlakuan atau post-test. Setelah didapat nilai dari hasil pre-test dan post-test langkah selanjutnya adalah menentukan rank atau peringkat dari masing-masing subjek penelitian sebelum diberikan perlakuan (X1) dan setelah diberikan perlakuan (X2) untuk dianalisis dengan menggunakan rumus uji Mann Whitney. Adapun hasilnya adalah sebagai berikut : 
Tabel 2. Data Analisis Rank

\begin{tabular}{llll}
\hline No. & Subjek & Nilai & Rank \\
\hline 1 & BM & 95 & 1 \\
2 & HV & 90 & 2 \\
3 & NG & 85 & 3 \\
4 & PA & 80 & 4 \\
5 & BM & 55 & 5 \\
6 & HV & 50 & 6 \\
7 & PA & 40 & 7.5 \\
8 & SA & 40 & 7.5 \\
9 & NG & 35 & 9 \\
10 & SA & 25 & 10
\end{tabular}

Tabel di atas membahas tentang analisis rank berdasarkan hasil dari pretest dan posttest yang telah dilakukan. Hasil tersebut selanjutnya diurutkan berdasarkan nilai tertinggi yang diberi peringkat satu dan seterusnya. Berdasarkan hasil tersebut terlihat bahwa BM mendapatkan nilai tertinggi dan mendapatkan ranking pertama dan SA mendapatkan rangking terakhir dengan nilai 25. Langkah selanjutnya yang dilakukan yaitu melakukan penghitungan rangking seperti tabel berikut:

Tabel 3. Penghitungan R1 dan R2

\begin{tabular}{llcccc}
\hline No & Subjek & X1 & X2 & R1 & R2 \\
\hline 1 & SA & 25 & 40 & 10 & 7.5 \\
2 & HV & 50 & 90 & 6 & 2 \\
3 & BM & 55 & 95 & 5 & 1 \\
4 & NG & 35 & 85 & 9 & 3 \\
5 & PA & 40 & 80 & 7,5 & 4 \\
\hline & Jumlah & 205 & 390 & 37.5 & 17,5 \\
\hline
\end{tabular}

Setelah dilakukan pengolahan data maka didapatlah angka-angka yang akan diolah menggunakan rumus. Selanjutnya data dimasukkan kedalam rumus uji Mann Whitney yang dikemukakan Nazir (2009: 404) dengan rumusan :

Analisis uji Mann Whitney sebagai berikut:

$$
\begin{aligned}
& \mathrm{U}_{1}=\mathrm{n}_{1} \cdot \mathrm{n}_{2}+\frac{\mathrm{n}_{2}\left(\mathrm{n}_{2}+1\right)}{2}-\sum \mathrm{R}_{2} \\
& \mathrm{U} 1=5.5+5(5+1)-17,5 \\
& \mathrm{U} 1=25+5(6)-17.5 \\
& \mathrm{U} 1=25+30-17.5 \\
& \mathrm{U} 1=25+15-17.5 \\
& \mathrm{U} 1=40-17,5 \\
& \mathrm{U} 1=22,5 \\
& \mathrm{U}_{2}=\mathrm{n}_{1} \cdot \mathrm{n}_{2}+\frac{\mathrm{n}_{1}\left(\mathrm{n}_{1}+1\right)}{2}-\sum \mathrm{R}_{1} \\
& \mathrm{U} 2=5.5+5(5+1)-37,5 \\
& \mathrm{U} 2=25+5(6)-37,5 \\
& \mathrm{U} 2=25+30-37,5 \\
& \mathrm{U} 2 \\
& \mathrm{U} 2=25+15-37,5 \\
& \mathrm{U} 2=40-37,5
\end{aligned}
$$

Keterangan :

$$
\begin{aligned}
& \text { U1/U2 = Koofisien U tes } \\
& \text { R1 } \quad \text { Rangking / peringkat pre-test } \\
& \text { R2 = Rangking/ peringkat post-test } \\
& \mathrm{n} 1=\text { Jumlah pre-test } \\
& \mathrm{n} 2=\text { Jumlah post-test }
\end{aligned}
$$

Dari hasil perhitungan diatas maka didapat Uhit $=2,5$ yang diambil dari nilai hitungan yang terkecil, selanjutnya disesuaikan dengan Utab pada taraf signifikan $95 \%$ dan $\alpha=0,05$ untuk $n=5$ yaitu 2 . 
Metode pembelajaran SQ4R adalah cara membaca yang dapat mengembangkan metakognitif anak, yaitu dengan menugaskan anak untuk membaca bahan belajar secara seksama, cermat, melalui survey anak mencermati teks bacaan, melihat pertanyaan di ujung bab. Question dengan membuat pertanyaan (mengapa, bagaimana dan darimana) tentang bahan bacaan (materi bahan ajar), Read dengan membaca teks dan mencari jawabannya. Reflect yaitu aktivitas memberikan contoh dari bahan bacaan dan membayangkan konteks actual yang relevan, Recite merupakan mempertimbangkan jawaban yang diberikan (catat-bahas bersama) dan Review yaitu cara meninjau ulang secara menyeluruh (Yusniar, 2015). Menurut Dewi (2016) Penerapan model pembelajaran SQ4R dapat meningkatkan aktivitas dan hasil belajar siswa kelas XI IPA 1 SMA N 1 Cepiring Kabupaten Kendal semester 2 tahun pelajaran 2015/ 2016, dari kondisi awal sampai siklus aktivitas belajar mengalami peningkatan. Dibia (2018:18) mengatakan bahwa berdasarkan hasil pengujian hipotesis dan pembahasannya terdapat perbedaan yang signifikan kemampuan membaca pemahaman siswa antara kelompok yang dibelajarkan dengan pembelajaran pembelajaran SQ4R berbantuan Satua Bali dan kelompok siswa yang dibelajarkan tidak dengan pembelajaran SQ4R berbantuan Satua Bali pada siswa kelas V SD di Gugus V Kintamani Tahun Pelajaran 2017/2018.

Penelitian ini membahas tentang efektivitas metode Survey, Question, Read, Recite, Reflect, Review (SQ4R) dalam meningkatkan keterampilan keterampilan membaca pemahaman bagi anak kesulitan belajar kelas III di SD N 14 Koto Panjang, Padang. Pada penelitian ini sebelum diberikan pretest peneliti memberikan dulu penjelasan mengenai keterampilan membaca pemahaman kemudian Pretest dilakukan satu kali untuk melihat kemampuan awal dalam keterampilan membaca pemahaman dan didapat hasil $41 \%$. Selanjutnya diberikan perlakuan atau treatment dengan menggunakan metode SQ4R diberikan kepada anak sebanyak 5 kali pertemuan, untuk tahap ini tidak dilakukan penilaian. Pada tahap ketiga yaitu posttest yang merupakan kemampuan akhir anak dalam keterampilan membaca pemahaman setelah diberikan perlakuan didapatl hasil $78 \%$.

Berdasarkan pengujian hipotetsis Ha diterima jika Uhit $>$ Utab dan $\mathrm{H} 0$ ditolak jika Uhit $\leq$ Utab.Dari hasil perhitungan yang telah dilakukan didapat Uhit $=3$ yang diambil dari nilai hitungan yang terkecil, selanjutnya disesuaikan dengan Utab pada taraf signifikan $95 \%$ dan $\alpha=0,05$ dan $n=5$ yaitu 0 . Uhit 3 dan Utab 0 berarti Uhit > Utab yaitu Ha diterima dan H0 ditolak. Jadi dapat disimpulkan bahwa metode SQ4R efektif dalam meningkatkan keterampilan membaca pemahaman bagi anak kesulitan belajar.

disajikan secara bersama dan membahas dengan jelas hasil- hasil penelitian. Hasil penelitian dapat disajikan dalam bentuk tertulis di dalam naskah, tabel, atau gambar. Kurangi penggunaan grafik karena hal tersebut dapat dijelaskan dalam naskah. Batasi pemakaian foto, sajikan foto yang jelas menggambarkan hasil yang diperoleh. Gambar dan tabel harus diberi nomor dan dikutip dalam naskah. Pembahasan yang disajikan hendaknya memuat tafsir atas hasil yang diperoleh dan bahasan yang berkaitan dengan laporan-laporan sebelumnya. Akan lebih baik jika rujukan yang digunakan merujuk ke Jurnal yang telah diterbitkan. Hindari mengulang pernyataan yang telah disampaikan pada metode, hasil dan informasi lain yang telah disajikan pada pendahuluan.

\section{Kesimpulan}

Berdasarkan uraian pada bab IV bahwa metode SQ4R efektif untuk meningkatkan keterampilan membaca pemahaman pada anak kesulitan belajar di kelas III SD N 14 Koto Panjang, Padang. Hal ini terbukti dari hasil perhitungan data yang diolah dengan menggunakan rumus uji Mann Whitney dimana hasil yang digunakan menggunakan hasil hitungan yang terkecil. Selanjutnya, hasil tersebut disesuaikan dengan Utab pada taraf signifikan $95 \%$. Berdasarkan pengujian hipotetsis Ha diterima jika Uhit > Utab dan H0 ditolak jika Uhit $\leq$ Utab. Jadi dapat disimpulkan bahwa metode Survey, Question, Read, Recite, Reflect, Review (SQ4R) efektif dalam meningkatkan meningkatkan keterampilan membaca pemahaman pada anak kesulitan belajar di kelas III SD N 14 Koto Panjang.

\section{Daftar Rujukan}

Abdurahman, Mulyono. (2012). Pendidikan Bagi Anak Kesulitan Belajar. Jakarta: Rineka Cipta.

Akkaya, N. (2011). İlköğretim 8. Sınıf Türkçe dersinde okuduğunu anlama stratejilerini kullanmanın, tutuma etkileri. Milli Eğitim Dergisi, $191,68-77$.

Arikunto, S. (2006). Prosedur Penelitian, Suatu Pendekatan Praktik. Jakarta: Rineka Cipta.

Aris, S. (2014). 68 model pembelajaran inovatif dalam kurikulum 2013. Yogjakarta: Ar-Ruzz Media.

Awada, G., \& Gutiérrez-Colón Plana, M. (2018). Multiple Strategies Approach and EFL Reading Comprehension of Learners with Dyslexia: Teachers' Perceptions. International Journal of Instruction, 11(113), 463-476. https://doi.org/10.12973/iji.2018.11332a

Balta, E.E. \& Demirel, Ş. (2012). Waldmann modelinin 8. Sınıf öğrencilerinin okuduğunu anlama ve eleştirel düşünme becerilerine etkisi. Turkish Studies 7(3), 469-479.

Başar, M., \& Gürbüz, M. (2017). Effect of the SQ4R technique on the reading comprehension of elementary school 4th grade elementary school students. International Journal of Instruction, 10(2 PG-131-144), 131-144. https://doi.org/10.12973/iji.2017.1029a

Dalman. (2013). Keterampilan Membaca. Bandar Lampung: Rajawali Pers.

Dewi, C.K (2016). Peningkatan Aktivitas Dan Hasil Belajar Sistem Ekskresi Melalui Penerapan Model Pembelajaran SQ4R bagi Siswa Kelas XI IPA 1 SMA Negeri 1 Cepiring Semester 2Tahun Pelajaran 2015/2016. Majalah Ilmiah Inspiratif, 2 (2), 1-10.

Dibia, K., Sudarma, K., Gunarsa, D. M. (2018). Pengaruh Strategi SQ4R Berbantuan Satua Bali Terhadap Kemampuan Membaca Pemahaman Siswa Kelas V. e-Journal PGSD, 6 (1), 10-19.

Edmonds, M. S., Vaughn, S., Wexler, J., Reutebuch, C., Cable, A., Tackett, K. K., \& Schnakenberg, J. W. (2009). A synthesis of reading interventions and effects on reading comprehension outcomes for older struggling readers. Review of educational research, 79(1), 262-300. https://doi.org/10.3102/0034654308325998

Ermanto. (2008). Keterampilan Membaca Cerdas. Padang: UNP PRESS.

Iswahyudi,G.,Budiyono,\& Wulandari, S (2016). Eksperimentasi Model Pembelajaran Survey, Question, Read, Recite, Review (SQ3R) dan Survey, Question, Read, Reflect, Recite, Review (SQ4R) Ditinjau dari Jenis Kelamin dan Gaya Belajar. Jurnal Elektronik Pembelajaran Matematika, 4 (1), 34-47.

Jamaris, M. (2009). Anak Berkesulitan Belajar Perseptif, Asesmen, dan Penanggulangannya. Jakarta: Yayasan Penamas Murni.

Joseph, L. M., Alber-Morgan, S., Cullen, J., \& Rouse, C. (2016). The Effects of Self-Questioning on Reading Comprehension: A Literature Review. Reading and Writing Quarterly, 32(2), 152-173. https://doi.org/10.1080/10573569.2014.891449

Khusniyah, N. L., \& Lustyantie, N. (2017). Improving English Reading Comprehension Ability through Survey, Questions, Read, Record, Recite, Review Strategy (SQ4R). English Language Teaching, 10(12), 202. https://doi.org/10.5539/elt.v10n12p202

Miller. J. W. (2016). World's Most Literate Nations Ranked. Diakses pada: https://webcapp.ccsu.edu/?news=1767\&data

Nazir. (2009). Metode Penelitian. Bogor: Ghalia Indonesia. 
Safaruddin, Efrina, E., \& Yunus, M. (2013). Pengaruh Program Jaws Terhadap Kemampuan Mengetik Pada Tunanetra Di Psbn Tuah Sakato Padang. Jurnal Pendidikan Khusus, 2(3), 408-418.

Soemarjadi. 1991. Pendidikan keterampilan. Jakarta: Depdikbud Dikti.

Sudarto, Z. (2017). Implementasi Kebijakan Penyelenggaraan Pendidikan Inklusif. Jurnal Pendidikan (Teori Dan Praktik), 1(1), $463-476$.

Taufan, J., \& Mazhud, F. (2016). Kebijakan-Kebijakan Kepala Sekolah Dalam Penyelenggaraan Pendidikan Inklusif Di Sekolah X Kota Jambi. Jurnal Penelitian Pendidikan, 14(1), 62-75.

Wahyuni, D. (2016). Penerapan Discovery Learning untuk Meningkatkan Kemampuan Membaca Pemahaman Siswa Kelas Vb Sd Negeri 004 Bukit Datuk Kota Dumai Tahun Pelajaran 2015/2016. E-Jurnal mitra pendidikan, 20, 79-90.

Wong, L. (2009). Essential Study Skills Sixth Edition. New York: Houghton Mifflin Company.

Yusniar, Rasjid. (2015). Pengaruh Model Pembelajaran Survey Question Read Reflect Recite Review (SQ4R) Dengan Metode Talking Stick Terhadap Keterampilan Metakognisi dan Hasil Belajar Biologi Siswa SMAN 9 Makassar. Jurnal BIOTEK, 3, 173- 183. 